\title{
COASTAL SUBSIDENCE IN OREGON, USA, DURING THE GIANT CASCADIA EARTHQUAKE OF AD 1700
}

\author{
A.D. Hawkes ${ }^{\mathrm{a}}$, B.P. Horton ${ }^{\mathrm{b}}$, A.R. Nelson ${ }^{\mathrm{c}}$, C. H. Vane ${ }^{\mathrm{d}}$, Y. Sawai ${ }^{\mathrm{e}}$ \\ ${ }^{\mathrm{a}}$ Geology and Geophysics Department, Woods Hole Oceanographic Institution, Woods Hole, MA 02543 \\ USA \\ ${ }^{\text {b}}$ Sea Level Research, Department of Earth and Environmental Science, University of Pennsylvania, \\ Philadelphia PA 19104 USA
}

${ }^{\mathrm{C} G e o l o g i c ~ H a z a r d s ~ T e a m, ~ U . S . ~ G e o l o g i c a l ~ S u r v e y, ~ M S ~ 966, ~ P O ~ B o x ~ 25046, ~ D e n v e r, ~ C o l o r a d o ~} 80225$ USA

${ }^{\mathrm{d}}$ British Geological Survey, Keyworth, Nottingham, NG12 5GG, UK

${ }^{\mathrm{e}}$ Active Fault Research Center, Geological Survey of Japan, National Institute of Advanced Industrial Science and Technology, Site C7 1-1-1 Higashi, Tsukuba 305- 8567, Japan

\begin{abstract}
Quantitative estimates of land-level change during the AD1700 giant Cascadia earthquake along the Oregon coastline are inferred from relative sea-level changes reconstructed from fossil foraminiferal assemblages preserved within the stratigraphic record. We apply a transfer functions based upon a regional training set of surface sediment samples from estuaries along the Oregon coast. The transfer function is calibrated to fossil assemblages across sharp peat-mud and peat-sand contacts to provide paleomarsh elevations and associated sample-specific errors. The elevation estimates are supported by lithological, carbon isotope, and faunal and floral zonation data. Coseismic subsidence from Nehalem River, Nestucca River, Salmon River, Alsea Bay, Suislaw River and South Slough varies between $0.18 \mathrm{~m}$ and $0.85 \mathrm{~m}$ with associated errors of $0.18 \mathrm{~m}$ to $0.32 \mathrm{~m}$. The quantitative estimates with increased precision compared to previous studies have implication for predictions of coseismic subsidence from elastic dislocation models, particularly in north-central Oregon. Our estimates constrain strain accumulation to 550 yrs or less with equivalent slip on the megathrust between 10 and $30 \mathrm{~m}$, which is consistent with the M9 earthquake for the AD 1700 earthquake.
\end{abstract}




\section{INTRODUCTION}

Continuing subduction of the Juan de Fuca plate beneath the North America plate exposes central western North America to major seismic hazard (e.g., Heaton and Kanamori, 1984; Atwater, 1987; Nelson et al., 1996a; Clague, 1997). Evidence of repeated mid- and late Holocene plate-boundary earthquakes are preserved in intertidal stratigraphic sequences along $1000 \mathrm{~km}$ coast of the Cascadia subduction zone (Atwater, 1987; Darienzo and Peterson, 1990; Atwater and Hemphill-Haley, 1997; Nelson et al., 1996b). Sequences of muddy tidal flat sediment that grade upward into the peaty horizons of tidal marsh soils form during periods of interseismic strain accumulation with slow relative sea-level (RSL) fall. The peaty soils are abruptly overlain by intertidal mud deposited following sudden coseismic subsidence of coastal marshes with nearly instantaneous RSL rise (e.g., Atwater et al., 1995; Atwater and Hemphill-Haley, 1997; Nelson et al., 1996b; Shennan et al., 1996; Kelsey et al., 2002; Witter et al., 2003). At some locations, tsunamis accompanying great megathrust earthquakes have abruptly buried marsh surfaces with sandy sediment (e.g., Clague et al., 1994; Darienzo et al., 1994; Nelson et al., 2004).

Estimating the amount of coseismic coastal subsidence is essential for mapping the coastal extent of plate-boundary ruptures and inferring the magnitude of megathrust earthquakes (Leonard et al., 2004; Hyndman et al., 2005; Nelson et al., 2006). Elastic dislocation models use the amount of coseismic subsidence to assist in the modeling of the length and width of ruptures and the amount of slip on the megathrust. The amount of coseismic subsidence at the surface of the overriding plate is directly related to the amount of slip and distance from the trench on the megathrust during rupture, and thus is also related to rupture length and earthquake magnitude (Hyndman and Wang, 1995; Leonard et al., 2004; Wang, 2003; Leonard et al., 2010).

All but the most recent estimates of coseismic subsidence at Cascadia are too imprecise to distinguish, for example, elastic from viscoelastic land-level movements (e.g., Wang, 2007), or to infer differences in the amount of subsidence or uplift from one earthquake cycle to the next (Nelson et al., 2008). Early work at accessible outcrops used suddenly buried plant macrofossils with broad elevational ranges to infer sudden coseismic subsidence (e.g., Atwater et al., 1991; Nelson et al., 1996b). Microfossils, such as diatoms and foraminifera, have also been used because of their sensitivity to differences in tidal exposure (e.g., Shennan et al., 1996). For example, Hemphill-Haley (1995) and Atwater and Hemphill-Haley (1997) used extensive diatom micropaleontology at southwestern Washington sites to estimate subsidence at 0.8-1.0 $\mathrm{m}$ (assuming no postseismic uplift) to $3 \mathrm{~m}$ (assuming postseismic uplift) during six of seven great earthquakes. However, these and other early microfossil studies were also semi-quantitative and relied on 
differences between intertidal elevational zones with broad ranges to estimate RSL changes (e.g., Nelson and Kashima, 1993; Darienzo et al., 1994, 1995; Hemphill-Haley, 1995, Nelson et al., 1996a; Atwater and Hemphil-Haley, 1997; Shennan et al., 1998; Williams and Hutchinson, 2000; Scott et al., 2001; Hawkes et al., 2005). In the late 1990s, application of transfer function analysis, widely used on microfossils from deep marine cores to reconstruct climate change, revitalized studies of Holocene sealevel change on many coasts (e.g., Horton et al., 1999; Gehrels et al. 2001; Horton and Edwards, 2006; Kemp et al., 2009) including Cascadia (e.g., Guilbault et al., 1995, 1996; Hughes et al., 2002; Sabean, 2004; Nelson et al., 2008; Hawkes et al., 2010).

Intertidal transfer functions develop relations between the relative abundance of microfossil species and environmental data, such as elevation. Calibration is then used to reconstruct past elevation from microfossil assemblages in cores or outcrops. When combined with lithostratigraphic data, the RSL reconstructions have precisions of \pm 0.1-0.3 m (e.g., Gehrels et al., 2008; Horton and Edwards, 2006; Kemp et al., 2009; Hawkes et al., 2010). With sufficient sample density, the transfer function provides a continuous record of RSL change during interseismic parts of the earthquake cycle; essential information for understanding the mechanics of plate-boundary ruptures in subduction zones.

Hawkes et al. (2010) developed a regional transfer function using an intertidal foraminiferal dataset from five Oregon estuaries. In this paper we apply the Hawkes et al. (2010) transfer function to fossil foraminiferal assemblages in samples from cores and sections that encompass the AD 1700 earthquake at Nehalem River, Nestucca River, Salmon River, Suislaw River and South Slough (Figure 1, 2). From transfer function derived paleomarsh elevations, we quantify the amount of sudden RSL rise across the contact between the pre- and post-seismic sediment, and thus infer the amount of coseismic subsidence along $400 \mathrm{~km}$ of the Oregon coast. We compare the foraminiferal estimates of coastal subsidence with predictions by dislocation modeling of megathrust ruptures (e.g., Leonard et al., 2004, 2010; Hyndman and Wang, 1995).

\section{STRATIGRAPHY OF THE AD 1700 EARTHQUAKE AT FIVE ESTUARIES}

Precise radiocarbon and tree-ring dating, combined with Japanese historical records, show that an earthquake near M9 occurred along the Cascadia subduction zone on 26 January AD 1700, probably about 9pm local time (Nelson et al., 1995; Satake et al., 2003; Atwater et al., 2005). We selected five field sites along $400 \mathrm{~km}$ of the Oregon coast (Figure 1) to estimate coseismic subsidence from this earthquake. To confirm identification of the contact marking the AD 1700 earthquake, we explored selected sites with 
a hand-operated gouge corer using criteria discussed by Atwater et al. (1995) and Nelson et al. (1996b). These criteria include: abrupt stratigraphic contacts $<1.5 \mathrm{~m}$ below the contemporary marsh surface between a peaty $\mathrm{A}$ or $\mathrm{O}$ soil horizon and overlying muddy unit; peaty horizon abruptly overlain by sand or silt that may have been deposited by a tsunami; and a peaty horizon that rises inland toward a buried Pleistocene surface but does not coalesce with other organic-rich horizons. These criteria in conjunction with published and unpublished radiocarbon dates are used to determine the AD 1700 earthquake horizon.

The Nehalem River coring site is 6 km up-estuary and protected by a 4 km-long, 0.7-km-wide sand spit (Figure 2a). We analyzed a vibracore taken on the south side of the river across from the contemporary training set of Hawkes et al. (2010). Grant (1994) and Minor and Grant (1996) found widespread stratigraphic and plant macrofossil evidence of subsidence during the AD 1700 earthquake exposed in bank sections over much of the lower estuary that traces landward for hundreds of meters. A sharp upper contact between the buried peaty horizon, including Native American fire hearths (Woodward, 1990), and an overlying muddy or sandy unit infer sudden subsidence during a megathrust earthquake (Grant, 1994; Minor and Grant, 1996). The mean age of eight radiocarbon-dated herbs rooted in the top of the buried peaty horizon at the outcrop at this site is AD 1666-1950 (179 $\pm 15{ }^{14} \mathrm{C}$ yrs BP; Nelson et al., 1995).

Nestucca Bay (Figure 2b) is protected from the ocean by 4-km-long, 0.9-km-wide sand spit. Our sampled bank section lies $500 \mathrm{~m}$ across the river from the Little Nestucca coring site of Darienzo (1991), Peterson and Darienzo (1988), and Darienzo et al. (1994) and north of sites cored by Witter et al. (2009). Between Nestucca River and Nestucca Bay, the uppermost buried peaty horizon is sharply overlain by intertidal mud and in some cases sandy units, inferred to be deposited by tsunamis (Darienzo, 1991; Witter et al., 2009). Radiocarbon dating near the upper contact of the buried peat indicates between AD 1410-1640 (Darienzo, 1991; Darienzo et al., 1994) and AD 1650-1950 from Witter et al. (2009).

At Salmon River we sampled a bank section 2 km up-estuary, which is protected by a 0.8-km-long, 0.5km-wide sand spit (Figure 2c). The contemporary data sampled in Hawkes et al. (2010) lies across the river to the north (Figure 2c). Grant (1994) and Minor and Grant (1996) described a continuous buried peaty horizon with a sharp contact to an overlying muddy or sandy unit. The peat included Native American fire hearths at one site. The mean of seven radiocarbon-dated herbs rooted in the top of the buried peaty horizon is AD 1667-1949 $\left(157 \pm 17{ }^{14} \mathrm{C}\right.$ yrs BP; Nelson et al., 1995, 2004; Bronk Ramsey, 2009). 
At Siuslaw River we took a vibracore on the northeast side of Cox Island, near sites analyzed by Briggs (1994) and Nelson et al. (1992b). This part of the estuary is about 9 km up-river and protected by a 5-kmlong, 1.5-km-wide sand spit. Hawkes et al. (2010) analyzed the contemporary intertidal zone on the northwest side of Cox Island (Figure 2d). The stratigraphy at Cox Island is complex; gradational and abrupt changes from muddy-peat to peaty-mud to mud are inferred to record both regional sea-level rise as well as interseismic and coseismic land-level changes over the last 2000 years (Nelson et al., 1992; Briggs, 1994). In a nearby outcrop to our vibracore, four radiocarbon ages from the youngest buried peaty horizon date to the past 400 years, with one date AD 1654-1950.

The South Slough core site, in the southwestern arm of the larger Coos Bay estuary, is $3 \mathrm{~km}$ from the sea (Figure 2e) and is protected by an 8-km-long, 2-km-wide sand spit. A Russian core was taken at Crown Point near the mouth of the slough, near the sites of Nelson et al. (1992, 1998), Darienzo et al. (1994), Briggs (1994) and Ota et al. (1995). Contemporary samples in the slough at Hidden Creek marsh are in the training set of Hawkes et al. (2010). Stratigraphy in South Slough and Coos Bay estuary consists of an upper buried peaty horizon abruptly overlain by muddy or sandy sediment (Briggs, 1994; Nelson et al., 1998). Two AMS radiocarbon ages from the uppermost buried peaty horizon in the slough and five from three other marshes in the bay are consistent with the timing of the AD 1700 earthquake (Nelson et al., 1992, 1996a, 1998).

\section{MATERIALS AND METHODS}

\subsection{Sampling and elevation measurement}

Sediment sequences encompassing the AD 1700 earthquake were described using the Tröel-Smith (1955) scheme of classification. Sediments were collected with monoliths from bank section and Russian hand core and vibracores from marsh surfaces. The bank sections and cores were leveled to temporary benchmarks and we continually measured water levels at each site over at least two successive high tides. These measurements were then compared to an independent tidal model that estimates tide levels for every $\sim 3 \mathrm{~km}$ (nodes) of the Oregon coast (Hawkes et al., 2010). Sediment sequences were sampled for foraminifera at $0.01 \mathrm{~m}$ intervals above and below the stratigraphical contact of the AD 1700 earthquake. We also sampled for carbon isotopes at South Slough.

\subsection{Microfossil, carbon isotope, and radiocarbon analyses}


We followed standard methods for foraminiferal sample preparation and analysis (e.g. Scott and Medioli,

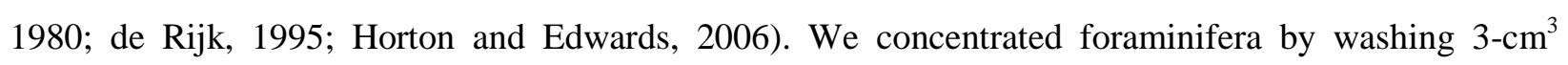
samples over $500 \mu \mathrm{m}$ and $63 \mu \mathrm{m}$ sieves and wet counted up to 300 specimens (where possible) in the 63$500 \mu \mathrm{m}$ size fraction. Foraminifera were identified with reference to the National Collection of Foraminifera, Smithsonian National Museum of Natural History (Plate I, Hawkes et al., 2010). We included foraminiferal test linings (e.g., Murray and Alve, 1999) and thecamoebians (e.g., Lloyd and Evans, 2002) as groups in our fossil assemblages. The occurrence of test linings may reflect postdepositional changes in foraminiferal assemblages (Edwards and Horton, 2000). The preservation of foraminifera is effected by the taphonomic processes they undergo during burial (Berkeley et al., 2007). For agglutinated forms, this threat comes from oxygenation of their organic cement and deterioration by microbes (Berkeley et al., 2007). For calcareous foraminifera, changes in the concentration of carbonic acid or bicarbonate and/or increases in hydrogen sulfide production (driven by the rate at which organic matter is supplied) favor the dissolution of calcium carbonate and therefore calcareous foraminifera (e.g., Berkeley et al., 2007).

In sediments at South Slough where foraminiferal abundances are too low or absent for quantitative paleoenvironmental reconstruction, we used carbon isotope analyses to determine $\delta^{13} \mathrm{C}$, total carbon (C), carbon-nitrogen ratio $(\mathrm{C} / \mathrm{N})$ and total nitrogen $(\mathrm{N})$. In general, a change from freshwater peat (-29 \%o) to saltwater peat (-28 \%o up to $-20 \%$ ) can be geochemically distinguished by $>1 \%$ shift in $\delta^{13} \mathrm{C}$, although there is some overlap in $\delta^{13} \mathrm{C}$ due to plant type, sediment mixing, and decomposition (Lamb et al., 2007; Kemp et al., 2010). Following the methodology of Kemp et al. (2010) core samples were treated with 5 \% hydrochloric acid to remove carbonates, washed in distilled water, and dried before homogenization in an agate ball mill. ${ }^{13} \mathrm{C} /{ }^{12} \mathrm{C}$ analyses were performed on treated sediments by combustion in a Carlo Erba 1500 on-line to a VG TripleTrap and Optima dual-inlet mass spectrometer, with $\delta^{13} \mathrm{C}$ values calculated to the VPDB scale using a within-run laboratory standard (cellulose, Sigma Chemical prod. no. C-6413) calibrated against NBS 19 and NBS 22. Replicate analyses of samples indicated a precision of $<0.1$ \% (1 $\mathrm{SD})$. $\mathrm{C} / \mathrm{N}$ ratios were analyzed on the same instrument; the ratios are calibrated with an acetanilide standard. Replicate analyses of well-mixed samples indicated a precision of $<0.1 \%$ (Lamb et al., 2007).

AMS radiocarbon dating was conducted at Nehalem River and Siuslaw River to identify the AD 1700 earthquake horizon within the stratigraphy. Plant macrofossils, such as Triglochin maritima, were used to derive precise radiocarbon ages in the underlying peaty-mud below the earthquake contact. Sample preparation followed Nelson et al. (2006) and calibrations by INTCAL04 (Reimer et al., 2004). 


\subsection{Foraminiferal training set and transfer function development and calibration}

Our estimates of coseismic subsidence during the AD 1700 earthquake are inferred from RSL changes reconstructed from fossil foraminiferal assemblages preserved within the stratigraphic record. Hawkes et al. (2010) collected a training set of surface sediment samples from five estuaries along the Oregon coast (Nehalem River, Salmon River, Siuslaw River, South Slough and Coquille River) to determine foraminiferal distributions and prevailing environmental control(s). They sampled the contemporary intertidal zones from above highest astronomical tide to lowest astronomical tide. The samples were taken in the fall to avoid the potential seasonal variation associated with the spring and summer species blooms (Horton and Edwards 2006; Horton and Murray, 2007). Dominant taxa in the regional dataset include Balticammina pseudomacrescens, Trochamminita irregularis, Haplophragmoides wilberti, Trochammina inflata, Jadammina macrescens and Miliammina fusca. Using unconstrained cluster analysis and detrended correspondence analysis Hawkes et al. (2010) identified two elevation-dependent faunal zones: Faunal Zone I (upland, high marsh, middle marsh) dominated by Balticammina pseudomacrescens, Haplophragmoides wilberti and Trochammina inflata, and Faunal Zone II (low marsh and tidal flat) dominated by Miliammina fusca. Canonical correspondence analysis (CCA) and partial CCA inferred that the zonation of foraminifera is elevation-dependent and subsequently a statistically significant transfer function to reconstruct changes in RSL could be developed. Since sites with differing tidal ranges are combined to form single training sets, it was necessary to standardize the elevation of each sample to take these differences in vertical range into account. This was achieved by converting the elevation of each sample to a standardized water level index (SWLI) following Horton and Edwards (2006):

$\mathrm{SWLI}=\left(\right.$ Elevation $\left.\left._{\mathrm{ab}}-\mathrm{MLLW}_{\mathrm{b}}\right) / \mathrm{MHHW}_{\mathrm{b}}-\mathrm{MLLW}_{\mathrm{b}}\right)$

where Elevation $_{\mathrm{ab}}$ is the elevation of sample a at site $\mathrm{b}$ (measured in m mean tide level, MTL); MLLW the mean low low water at site b (m MTL); and $\mathrm{MHHW}_{\mathrm{b}}$ is the mean high high water a site b (m MTL). The results of a weighted averaging partial least squares (WA-PLS) transfer function using a regional training set indicate a robust performance between the observed and foraminiferal-predicted elevations $\left(\mathrm{r}^{2}\right.$ jack $\left.=0.90\right)$.

In this paper we calibrate the transfer functions to fossil assemblages to provide paleomarsh elevations

and sample-specific errors. The predicted values of SWLI are converted to estimates of elevation by rearranging Equation 1 and inputting the appropriate tidal parameters for the site from which the fossil sequence was recovered. This back-transformation process results in the elevations being expressed in 
meters relative to MSL. We estimate coseismic subsidence in sedimentary sequences using the following equations:

$S_{C}=E_{\text {pre }}-E_{\text {post }}$

where, coseismic subsidence $\left(\mathrm{S}_{\mathrm{C}}\right)$ is estimated by subtracting the paleomarsh elevation of the pre-seismic sample $\left(E_{\text {pre }}\right)$ within the buried peaty horizon from the post-seismic sample $\left(E_{\text {post }}\right)$ in the overlying clastic unit. We disregard samples from inferred tsunami deposited sediments.

$\mathrm{S}_{\mathrm{C}}$ error $=\sqrt{ }\left[\left(\mathrm{E}_{\text {pre }} \text { error }\right)^{2}+\left(\mathrm{E}_{\mathrm{post}} \text { error }\right)^{2}\right]$

where, the coseismic subsidence error ( $S_{C}$ error) is calculated from the sample-specific $E_{\text {pre }}$ error and $E_{\text {post }}$ error provided by the WA-PLS transfer function.

Following this methodology, Hawkes et al. (2010) calibrated the transfer function to a fossil sequence at Alsea Bay of the AD 1700 earthquake to address previous inconsistent transfer function reconstructions between foraminifera and diatom training sets (Nelson et al., 2008). Estimates of coseismic subsidence for the $\mathrm{AD} 1700$ earthquake using foraminifera were $0.40 \mathrm{~m} \pm 0.19 \mathrm{~m}$ and $0.16 \mathrm{~m} \pm 0.12 \mathrm{~m}$ using diatoms. Nelson et al (2008) noted that evaluation of subsidence estimates are complicated by fossil foraminifera with $30 \%$ 'no close' analogues, because the contemporary dataset lacked species encountered in the fossil samples. Increasing the environmental diversity in the contemporary dataset improves the likelihood of a modern analogue. Hawkes et al. (2010) applied their transfer function to the fossil foraminiferal data of Nelson et al. (2008). The expanded regional dataset with a consistent taxonomy produced an estimate of coseismic subsidence $(0.18 \pm 0.31 \mathrm{~m})$ with each of the fossil samples possessing a matching analogue. The foraminiferal-predicted coseismic subsidence was comparable to the reconstruction using a diatom-based transfer function.

\subsection{Evaluating the completeness of estuarine sedimentation}

A concern over using microfossil methods to reconstruct coseismic and immediately postseismic landlevel changes is that too little tidal sediment may be deposited in the first few weeks following coseismic movements (Hemphill-Haley, 1995; Leonard et al., 2004). Following Guilbault et al. (1996), Hughes et al. (2002) and Nelson et al. (2008) we infer that no breaks of weeks or more in tidal sedimentation occurred following great earthquakes and accompanying tsunamis, if a tsunami-deposit overlies buried peaty horizons, and that deposit grades upward into tidal mud with no identifiable disconformities. At 
such sites, we infer that sedimentation was continuous and that microfossil assemblages reflect elevational environments to the same extent that they do during interseismic periods with lower sedimentation rates. Further support is provided by the colonizing ability of foraminifera, which are capable of colonizing within weeks of a disturbance, such as an earthquake (e.g., Alve, 1995; Alve and Goldstein, 2002; Langezaal et al., 2003; Horton et al., 2009).

The study of foraminiferal abundance and composition within fossil samples assists with identifying tsunami deposits where a change in lithology is uncertain (Hawkes et al., 2007). The composition of assemblages transported by tsunami inundation and backwash may be distinct because turbulent tsunami waves inundate coastal inland areas transporting and redepositing marine and brackish foraminifera (e.g. Hawkes et al., 2007; Mamo et al., 2009). We apply the modern analogue technique (MAT) to identify these allochthonous assemblages (Birks, 1995). Because the foraminiferal assemblages within tsunami sediments are not included in the contemporary training set, dissimilarity coefficients for these samples are often high. The maximum dissimilarity coefficient of the contemporary training set of Hawkes et al. (2010) is used as a threshold between 'good' and 'no close' analogue in the fossil samples (Woodroffe, 2009). The modern analogue technique should indicate 'no close' modern analogues for the assemblages transported by tsunami inundation.

\section{RESULTS}

\subsection{Nehalem River}

At Nehalem River we sampled a peaty horizon sharply overlain (contact $\leq 2 \mathrm{~mm}$ ) by sandy silt, which represents the $\mathrm{AD} 1700$ earthquake. The buried peat, from $1.32 \mathrm{~m}$ to $1.22 \mathrm{~m}$ depth, consists of a greybrown silty-clay with organic material including roots and wood fragments (Figure 3a). The foraminiferal assemblages from the peat indicate a high to middle marsh environment dominated by $H$. manilaensis, $B$. pseudomacrescens and T. irregularis (Hawkes et al., 2010).The overlying light brown-grey silty fine sand (1.22 $\mathrm{m}$ to $1.08 \mathrm{~m}$ depth) has minimal root and plant fragments. The foraminiferal assemblage is dominated by $M$. fusca and $J$. macrescens indicating a switch to a low marsh-tidal flat environment.

Transfer function reconstructions showed that paleomarsh elevations throughout the buried peat range between $1.02 \mathrm{~m}$ and $1.33 \mathrm{~m}$ MSL supporting the foraminiferal and lithological interpretations of a high to middle marsh depositional environment. We estimate the pre-seismic ( $\left.E_{\text {pre }}\right)$ elevation was $1.02 \pm 0.21 \mathrm{~m}$ from 1.22 m depth; MAT indicates the sample has a good analogue. Reconstructing post-seismic sample 
$\left(E_{\text {post }}\right)$ in the overlying clastic unit is complicated because of the absence of an obvious stratigraphic unit indicative of tsunami deposition. However, between $1.22 \mathrm{~m}$ and $1.15 \mathrm{~m}$ depth MAT identified three samples with 'no close' analogues. Further planktonic species and high abundances of Ammobaculites sp., a taxon indicative of subtidal environments at Nehalem, are present. The occurrence of these species likely represents deposition by tsunami (Dawson et al., 1996; Mamo et al., 2009). Therefore, we have selected $1.14 \mathrm{~m}$ depth to represent the post seismic sample $\left(\mathrm{E}_{\mathrm{post}}=0.53 \pm 0.23 \mathrm{~m}\right)$. MAT indicates this sample has a good analogue and the foraminiferal data are indicative of a low marsh-tidal flat environment, which supports the lithological data. Using Equations 2 and 3 we estimate $0.49 \mathrm{~m} \pm 0.31 \mathrm{~m}$ of coseismic subsidence at Nehalem River.

\subsection{Netucca River}

At Nestucca River we sampled a peaty horizon between $1.12 \mathrm{~m}$ to $1.05 \mathrm{~m}$ depth, which is composed of brown organic-rich clayey-silt with root fragments (Figure 3b). The buried peat is sharply overlain (contact $\leq 1 \mathrm{~mm}$ ) by $0.06 \mathrm{~m}$ of medium gray sand from $1.05 \mathrm{~m}$ to $0.99 \mathrm{~m}$ depth. The sand grades upward into a grey silt from $0.99 \mathrm{~m}$ to $0.80 \mathrm{~m}$ depth. B. pseudomacrescens and $H$. wilberti dominated the foraminiferal assemblage in the peat indicating a high to middle marsh environment. $B$. pseudomacrescens and $H$. wilberti are also present in the sand but at much lower total abundances. In grey silt the foraminifera indicate a low marsh environment derived from an assemblage dominated by $J$. macrescens and $M$. fusca.

Reconstruction of paleomarsh elevations in the peaty horizon ranged between $1.28 \mathrm{~m}$ and $1.44 \mathrm{~m}$ MSL. We estimate the pre-seismic $\left(\mathrm{E}_{\mathrm{pre}}\right)$ elevation from the sample immediately below the stratigraphic contact (1.05 m depth) to be $1.38 \mathrm{~m} \pm 0.20 \mathrm{~m}$ MSL. Selecting a reconstructed post-seismic sample in the overlying clastic unit is straightforward because the sand unit has been interpreted to be a tsunami deposit (Darienzo, 1991; Darienzo et al., 1994; Witter et al., 2009). Further, MAT showed a 'no close' analogue for one sample in the tsunami sand at $1.02 \mathrm{~m}$ depth. The post-seismic sample above the sand $\left(\mathrm{E}_{\text {post }}=0.95\right.$ $\mathrm{m}$ depth) provides a paleomarsh elevation of $0.91 \mathrm{~m} \pm 0.20 \mathrm{~m}$ MSL. Coseismic subsidence is estimated to be $0.47 \mathrm{~m} \pm 0.28 \mathrm{~m}$.

\subsection{Salmon River}

At Salmon River we sampled a peaty horizon composed of dark grey organic-rich silt from $1.09 \mathrm{~m}$ to 0.99 $\mathrm{m}$ depth (Figure 3c). The peat is sharply overlain (contact $\leq 2 \mathrm{~mm}$ ) by $0.04 \mathrm{~m}$ thick dark grey coarse sand. The sand grades into a grey clayey-silt from $0.95 \mathrm{~m}$ to $0.85 \mathrm{~m}$ depth. The peat is composed of a 
foraminiferal assemblage containing B. pseudomacrescens, T. inflata and H. wilberti indicating a high marsh environment. The sand has a mixed foraminiferal assemblage, including marine and brackish taxa. The assemblage in the clayey-silt is dominated by $M$. fusca and J. macrescens indicating a low marsh environment, although the sample at $0.91 \mathrm{~m}$ depth has anomalously high relative abundances of $J$. macrescens (75 \%).

The transfer function reconstructions varied between $1.33 \mathrm{~m}$ to $1.44 \mathrm{~m}$ MSL in the peaty horizon and between $0.52 \mathrm{~m}$ and $0.96 \mathrm{~m}$ MSL in the clayey-silt. We estimate the pre-seismic $\left(\mathrm{E}_{\mathrm{pre}}\right)$ elevation from the sample immediately below the stratigraphic contact ( $0.99 \mathrm{~m}$ depth) to be $1.41 \mathrm{~m} \pm 0.21 \mathrm{~m}$ MSL. The sand between $0.99 \mathrm{~m}$ to $0.95 \mathrm{~m}$ depth has been interpreted by Grant $(1994)$ and Nelson et al $(1995,2004)$ to be a tsunami deposit. Further MAT showed a 'no close' analogue for the foraminiferal assemblage at $0.94 \mathrm{~m}$ depth. We reconstruct the post-seismic elevation $\left(E_{\text {post }}\right)$ from the overlying sample (0.93 $\mathrm{m}$ depth), which is $0.81 \mathrm{~m} \pm 0.20 \mathrm{~m}$ MSL. We estimate coseismic subsidence to be $0.60 \mathrm{~m} \pm 0.29 \mathrm{~m}$.

\subsection{Siuslaw River}

At Siuslaw River we sampled a brown organic-rich peat that occurs between $0.64 \mathrm{~m}$ to $0.56 \mathrm{~m}$ (Figure 3d). The peat is sharply overlain ( $\leq 1 \mathrm{~mm}$ contact) by a $0.04 \mathrm{~m}$-thick fine grey sand. The upper contact of the sand at $0.52 \mathrm{~m}$ depth is relatively abrupt $(3 \mathrm{~mm})$ and is overlain by a brown-grey clayey-silt, suggesting incomplete estuarine sedimentation. The foraminiferal assemblages within the peat are dominated by $B$. pseudomacrescens and T. inflata, indicative of a high marsh environment. This assemblage is abruptly replaced in the sand with a low abundance, monospecific assemblage of $J$. macrescens. Foraminifera were absent from samples $0.53 \mathrm{~m}$ and $0.52 \mathrm{~m}$ depth. The clayey-silt is also dominated by high relative abundances of $J$. macrescens with two monospecific samples at $0.50 \mathrm{~m}$ and 0.49 m depth.

Reconstructions for the transfer function in the peaty horizon were between $1.08 \mathrm{~m}$ to $1.32 \mathrm{~m}$ MSL. The pre-seismic ( $E_{\text {pre }}$ ) elevation from the sample immediately below the stratigraphic contact ( $0.56 \mathrm{~m}$ depth) is $1.08 \mathrm{~m} \pm 0.21 \mathrm{~m}$ MSL. The sand from $0.56 \mathrm{~m}$ to $0.52 \mathrm{~m}$ depth has been interpreted to be a tsunami deposit. MAT showed 'no close' analogues for samples both within the sand and overlying clayey silt due to high relative abundances of $J$. macrescens, which do not occur in the training set of Hawkes et al. (2010). The selected post-seismic elevation $\left(E_{\text {post }}\right)$ of $0.67 \mathrm{~m} \pm 0.22 \mathrm{~m}$ MSL from $0.51 \mathrm{~m}$ depth is potentially unreliable. Due to problems of analogues in the modern dataset and incomplete sedimentation 
suggested by the lithology following the earthquake, we tentatively estimate coseismic subsidence to be $0.42 \mathrm{~m} \pm 0.30 \mathrm{~m}$.

\subsection{South Slough}

We sampled a dark brown peaty horizon from $0.60 \mathrm{~m}$ to $0.40 \mathrm{~m}$ depth, which is sharply overlain (3 $\mathrm{mm}$ contact) by a thin $3 \mathrm{~cm}$ coarse grey sand at South Slough. The sand grades into a grey silty-clay from 0.38 $\mathrm{m}$ to $0.30 \mathrm{~m}$ depth (Figure 3e). At the base of the peat from 0.60 to $0.56 \mathrm{~m}$ depth the foraminiferal assemblage is dominated by $T$. irregularis and $B$. pseudomacrescens indicating a high marsh environment. Foraminifera are absent within the remainder of the peat, suggesting a freshwater environment. Carbon isotope analyses showed a change in composition at $0.56 \mathrm{~m}$ depth (-25.0 to -27.5 \%o in $\delta^{13} \mathrm{C}$ ), which supports a transition from salt marsh toward freshwater depositional environment (Lamb et al., 2007; Kemp et al., 2010). From $0.54 \mathrm{~m}$ to $0.40 \mathrm{~m}$ depth, high percentages of total organic carbon and total nitrogen imply the peaty horizon is an upland soil (Lamb et al., 2007). At the contact with the overlying sand, total organic carbon and total nitrogen decrease reflecting a return from freshwater to brackish conditions (Lamb et al., 2007). Very low abundances of foraminifera are found at the upper contact of the sand, but numbers increase within the silty-clay. The assemblage is composed of $T$. inflata and J. macrescens indicative of a middle marsh environment. Anomalously high abundances of $T$. irregularis are found at 0.55 depth, which are absent in the modern environment (Hawkes et al., 2010).

The absence of foraminifera and carbon isotope analyses indicate that the peat below the stratigraphic contact of the AD 1700 earthquake is a freshwater environment forming above highest astronomical tide. In the modern transect at South Slough (Hawkes et al., 2010) foraminifera are absent above $1.55 \mathrm{~m}$ MSL, thus providing a minimum pre-seismic $\left(\mathrm{E}_{\text {pre }}\right)$ elevation. In the silty clay, foraminifera produced estimates of paleomarsh elevations between $0.70 \mathrm{~m}$ and $1.16 \mathrm{~m}$ MSL, which all have good matching analogues. The post-seismic $\left(E_{\text {post }}\right)$ elevation from the sample $(0.38 \mathrm{~m}$ depth) immediately above the tsunami sand (Briggs, 1994; Nelson et al., 1998) is $0.70 \mathrm{~m} \pm 0.18 \mathrm{~m}$. The minimum coseismic subsidence is $0.85 \mathrm{~m}$.

\section{COSEISMIC SUBSIDENCE OF AD 1700 EARTHQUAKE}

Grant (1994) and Minor and Grant (1996) suggested that Nehalem River experienced a change from a spruce forest to a Triglochin maritima colonized mudflat, producing $1 \mathrm{~m}$ to $2 \mathrm{~m}$ coseismic subsidence. We measured substantially less subsidence $(0.49 \pm 0.31 \mathrm{~m})$ at the more seaward of their two most-studied sites. We believe the published studies overestimated the amount of subsidence, because Triglochin maritima is also common in the modern low and middle marsh environments (Eilers, 1975; Hawkes et al., 
2010). Triglochin maritima is also much more resistant to decay than many other marsh plants, and so may persist in the sediments of buried low and middle marshes after other species have decomposed. At

Nestucca River estimates of coseismic subsidence from Darienzo (1991), Peterson and Darienzo (1988) and Darienzo et al. (1994) overlap (0.5 m-1.5 m) at the lower end with estimates from the foraminiferalbased transfer function $(0.47 \mathrm{~m} \pm 0.28 \mathrm{~m})$. The published studies were based upon lithology, qualitative diatom analysis, percent organic content, and the presence of Triglochin maritima plant macrofossils presumed to be indicative of a mudflat.

The foraminiferal transfer function derived estimates $0.60 \pm 0.29 \mathrm{~m}$ at Salmon River are consistent with previous studies. Nelson et al. (2004) used limited pollen and plant macrofossil data to estimate 0.3 to 1.0 m of coseismic subsidence during the AD 1700 earthquake. Grant (1994) and Minor and Grant (1996) used lithology and macrofossils to estimate that as little as $0.5 \mathrm{~m}$ or as much as $1.0 \mathrm{~m}$ of subsidence could have changed a high marsh to an unvegetated tidal flat in AD 1700.

At Siuslaw River the estimated amount of coseismic subsidence varies as the result of complex stratigraphy. Briggs (1994) used lithology, qualitative diatom analysis, and organic content to infer subsidence of $1.0 \mathrm{~m}$ to $2.0 \mathrm{~m}$ during the AD 1700 earthquake. Alternatively, Nelson (1992) interpreted gradual changes between peat and mud lithofacies at Siuslaw River as reflecting coseismic subsidence of $<1 \mathrm{~m}$ and probably $<0.5 \mathrm{~m}$. Our quantitative estimate of coseismic subsidence $(0.42 \mathrm{~m} \pm 0.32 \mathrm{~m}$ ) supports lower values, although the transfer function results are compromised by 'no close' analogues in overlying clastic sediments where the $\mathrm{E}_{\text {post }}$ sample is selected.

Previous estimates of coseismic subsidence during the $\mathrm{AD} 1700$ earthquake in South Slough are comparable. Nelson et al. (1992, 1996a, 1998) using changes in lithology and plant macrofossils suggest subsidence $>0.5 \mathrm{~m}$. Briggs (1994) estimated that for a supratidal marsh or forest surface to be buried by muddy sediments would require a minimum subsidence of $1.0 \mathrm{~m}$ to $2.0 \mathrm{~m}$. Estimates of coseismic subsidence from a foraminifera-based transfer function developed by Nelson et al. (2008) including the fossil data of Nelson et al. (1996a) and contemporary data of Jennings and Nelson (1992) produced subsidence estimates of $0.7 \pm 0.3 \mathrm{~m}$. Our regional foraminiferal-based transfer function calculates a minimum elevational change of 0.85 m near the mouth of South Slough.

The differences in magnitude and uncertainty of coseismic subsidence between our quantitative reconstructions using a consistent methodology and the qualitative estimates based upon a variety of 
lithological and macro- and microfossil methods are manifest in Leonard et al. (2004, 2010) compilation of estimates for the AD 1700 earthquake from British Columbia to Northern California (Table 1). Notwithstanding the large errors (uncertainties of typically \pm 0.5-0.8 m), Leonard et al.’s $(2004,2010)$ database proposes coseismic subsidence of up to $2 \mathrm{~m}$ for the Oregon coastline. We find that our quantitative estimates $(0.18 \mathrm{~m} \mathrm{t} @ 0.85 \mathrm{~m})$ are lower, especially at Nehalem and $\mathrm{Ne}$ stucca rivers. As suggested by Nelson et al. (2008), modest coseismic subsidence estimates for the Oregon coast restrict plate boundary ruptures from extending far inland. Hyndman (2005) showed that by varying the width of the rupture zone, using values consistent with uncertainties in the thermal and geodetic seismogenic zone, had little effect on surface deformation. Hyndman (2005) inferred that surface deformation is primarily affected by slip along the shallower part of the megathrust. But if the amount of slip is equal to the amount of strain accumulation (550 yrs or $800 \mathrm{yrs),} \mathrm{an} \mathrm{increase} \mathrm{in} \mathrm{rupture} \mathrm{width} \mathrm{increases} \mathrm{the} \mathrm{magnitude}$ of vertical deformation of the surface. The same results can also be modeled by varying the amount of megathrust slip (Leonard et al., 2004).

Leonard et al. (2004) compared coseismic subsidence from the database of the A.D. 1700 megathrust earthquake with predictions from elastic dislocation models constrained by geophysical (geodetic, thermal, seismic) data of Okada (1985), Hyndman and Wang, (1993, 1995) and Flück et al. (1997). The study showed that a simple elastic dislocation model of the seismic release of 550-800 years of accumulated strain can produce coastal subsidence generally consistent with the database. Leonard et al. (2004) concluded that the penultimate great megathrust event to have occurred $\sim 600-1000$ years prior to the A.D. 1700 earthquake (e.g., Atwater and Hemphill-Haley, 1997). However, turbidite analyses and some coastal data place the penultimate event at only 200 years prior to A.D. 1700 (e.g., Goldfinger et al., 2008). We find that the transfer function estimates of subsidence for Nehalem River, Alsea Bay and South Slough are comparable to modeled strain accumulation rate of 550 years or less and do not overlap the 800 year rate. However, Nestucca River, Salmon River and Siuslaw River overlap both the 550 year and 800 year accumulation rates (Figure 4a). The assertion of a lower strain rate supports the more recent study of Leonard et al. (2010). Aware of differences in the precision of studies of coseismic subsidence, they graded the estimates into three quality levels and compared these observations with predictions of coastal subsidence based on the CAS3D elastic dislocation model (Wang et al., 2003). Leonard et al. (2010) concluded that the Oregon coastline is broadly consistent with the pattern of coseismic displacements predicted for the full release of strain accumulated over 500 years.

Estimation of slip magnitude in the AD 1700 earthquake was possible through comparisons between uniform slip model predictions and the coseismic subsidence database (Leonard et al., 2004, 2010). Their 
best-fit slip pattern (Figure 4b) suggested the region of greatest slip in northern Oregon ( $\geq 30 \mathrm{~m}$ ), decreasing along the coast to the south to less than $10 \mathrm{~m}$. Our transfer function-derived estimates of coseismic subsidence indicate a near-constant coseismic slip. No sites suggest $50 \mathrm{~m}$ of slip on the megathrust. Nehalem River, Alsea Bay and South Slough infer less than $20 \mathrm{~m}$ of slip whereas Nestucca River, Salmon River and Siuslaw River suggest between 20 m and 30 m of slip. Fault rupture of 10-30 m is consistent with the M 9 earthquake (Leonard et al., 2004, 2010).

Leonard et al. (2004, 2010) noted that in southern Oregon subsidence estimates, even with the large errors included in the database, are significantly less than predicted by the elastic dislocation models. The simple models did not include the complex deformation near the Mendocino triple junction, thus the coastal data may be better fit by a model with a $25 \%$ narrower rupture (Leonard et al., 2010). Leonard et al. (2010) concluded that future studies should focus on the transfer function methodology used in this paper to increase the quality and reduce the uncertainty $( \pm 0.2-0.3 \mathrm{~m})$ of coseismic subsidence estimates, particularly in southern Oregon.

\section{CONCLUSIONS}

It has long been established that the interchange between terrestrial and marine sediments can provide information on RSL change and plate boundary earthquakes. Paleoseismologists infer the amount of coseismic subsidence during plate-boundary earthquakes from lithostratigraphic and plant macrofossil changes in across sharp peat-mud and peat-sand contacts. However, the use of lithostratigraphic-based reconstructions is associated with a number of limitations, and these become particularly significant when examining low amplitude (>1 m), short period (hours-days) variations that occur during a plate-boundary earthquake. Reconstructed paleomarsh elevations derived from applying the Hawkes et al. (2010) foraminiferal-based transfer function were used to estimate coseismic subsidence immediately following the $\mathrm{AD} 1700$ giant earthquake from stratigraphic sequences at five salt marshes along the Oregon coast. The results at Nehalem River indicated $0.49 \mathrm{~m} \pm 0.31 \mathrm{~m}$ of coseismic subsidence; Nestucca River $0.47 \mathrm{~m}$ $\pm 0.28 \mathrm{~m}$ and Salmon River $0.60 \mathrm{~m} \pm 0.29 \mathrm{~m}$; and Alsea Bay $0.18 \mathrm{~m} \pm 0.31$. Estimates from Siuslaw River of $0.42 \mathrm{~m} \pm 0.32 \mathrm{~m}$, must be observed with caution due to 'no close' matching analogues in the post-earthquake sediments. At South Slough we estimate minimum coseismic subsidence of $0.85 \mathrm{~m}$ because foraminifera are absent in the pre-earthquake sediments. Coseismic subsidence estimates are supported lithostratigraphy and faunal zonation, and carbon isotope analyses. AD 1700 giant earthquake coseismic subsidence estimates produced by the foraminiferal-based transfer function are quantitative and reduce uncertainty when compared to previous qualitative estimates. Comparisons to modeled predictions 
of Leonard et al $(2004,2010)$ point to strain accumulation of 550 yrs and slip on the megathrust of between $10-30 \mathrm{~m}$.

\section{ACKNOWLEDGEMENTS}

This research was supported by National Science Foundation award (EAR-0842728). A.D. Hawkes would like to thank supporting agencies; United State Geological Survey, Society of Sedimentary Geology (SEPM - Sanders Student Research Fund), the University of Pennsylvania paleo-stipend, and NOSAMS for AMS radiocarbon dating. Both, A.D. Hawkes and A.R. Nelson acknowledge partial support from the Earthquake Hazards Program of the USGS. C.H. Vane publishes with permission of the Director of the British Geological Survey. Y. Sawai was supported by the Geological Survey of Japan. Rob Witter, Andrew Kemp, Simon Engelhardt and Candace Grand Pre contributed to field sampling.

\section{FIGURE AND TABLE CAPTIONS AND FIGURES}

Figure 1. Pacific Northwest of central North America major features of the Cascadia subduction zone (modified from Atwater and Hemphill-Haley, 1997; Clague, 1997; Nelson et al., 2008) showing the location (black circles) of Nehalem River, Nestucca River, Salmon River, Siuslaw River and South Slough along the Oregon coast. The Cascadia megathrust fault is shown (black barbed line). Small dots mark locations with evidence of subsidence or tsunami deposits (Atwater et al., 1995; Clague et al., 2000; Nelson et al., 2006)

Figure 2. Location of core and transect sample sites (black circles) at a) Nehalem River, b) Nestucca River, c) Salmon River, d) Siuslaw River and e) South Slough. Contemporary transects are located by dashed lines at sites where they are near the core site $(<250 \mathrm{~m})$.

Figure 3. a) Stratigraphy, percent foraminifera, and type of transfer function analysis (WA-PLS) used to reconstruct RSL changes in the sediment sequence encompassing the AD 1700 earthquake at (a) Nehalem River; (b) Nestucca River; (c) Salmon River; (d) Siuslaw River; and (e) South Slough. Shaded grey areas mark sections of core where samples were not used to estimate the amount of coseismic subsidence (this includes tsunami sediment where present), the sample immediately under $\left(E_{\text {pre }}\right)$ and on top ( $\left.E_{\text {post }}\right)$ of the box are used in the subsidence equation (Eq. 2) and sample-specific error equation (Eq. 3). Dissimilarity coefficient values with no matching analogue assemblage in the contemporary training set assemblages are identified by solid black squares or triangles (tsunamis), and so the reliability of reconstructed 
elevations derived from these samples is difficult to evaluate and these samples were not used in coseismic subsidence calculations, with the exception of Siuslaw River. The star symbol in (e) identifies the inferred elevation of the sediment underlying the AD 1700 contact. The elevation was inferred from Hawkes et al., 2010 as above the height of upper sample in the modern dataset. Calculated coseismic subsidence is noted with associated error estimates in meters to the right of each reconstruction.

Figure 4. Cascadia coseismic subsidence estimates from this study (boxes) compared with weighted mean of groups of coseismic subsidence estimates based on qualitative estimates and their standard deviation (grey shaded area) from Leonard et al. (2004, 2010). Elastic dislocation model of (A) strain accumulation since the last earthquake of 550 years and 800 years, and (B) uniform slip on the megathrust of $10 \mathrm{~m}, 20$ m, $30 \mathrm{~m}$ and 50 m. (C) Coseismic subsidence estimates calculated using Eq 2 using Hawkes et al. 2010 transfer function applied to five stratigraphic sequences spanning the AD 1700 earthquake at five sites in coastal Oregon. The box for Siuslaw River is grey because $\mathrm{E}_{\text {post }}$ all had no matching analogues in the modern dataset. The box for South Slough is open-ended at the top because this is considered a minimum estimate.

Table 1. Location of coseismic subsidence estimates. Leonard et al. (2004, 2010) semi-quantitative subsidence estimate ranges and subsidence estimate weighted mean and mean uncertainty (Leonard et al., 2010) compared to our quantitative coseismic subsidence estimates.

\section{REFERENCES}

Alve, E., 1999. Colonization of new habitats by benthic foaminifera: a review. Earth-Science Reviews, 46: $167-185$.

Alve, E., Goldstein, S. T., 2002. Resting stage in benthic foraminiferal propagules: a key feature for dispersal? Evidence from two shallow water species. Journal of Micropalaeontology, 21: 95-96.

Atwater, B.F., 1987. Evidence for Great Holocene earthquakes along the outer coast of Washington State. Science, 236: 942-944.

Atwater, B.F., Stuiver, M., Yamaguchi, D.K., 1991. A radiocarbon test of earthquake magnitude at the Cascadia subduction zone. Nature, 353: 156-158. 
Atwater, B.F. 1992. Geologic evidence for earthquakes during the past 2000 years along the Copalis River, southern coastal Washington. Journal of Geophysical Research, 97: 1901-1919.

Atwater, B.F., Hemphill-Haley, E., 1997. Recurrence intervals for great earthquakes of the past 3500 years at northeastern Willapa Bay, Washington. U.S. Geological Survey Professional Paper, 1576: 108 p.

Atwater, B.F., Nelson, A.R., Clague, J.J., Carver, G.A., Bobrowsky, P.T., Bourgeois, J., Darienzo, M.E., Grant, W.C., Hemphill-Haley, E., Kelsey, H.M., Jacoby, C.G., Nishenko, S.P., Palmer, S., Peterson, C.D., Reinhart, M.A., Yamaguchi, D. K., 1995. Summary of coastal geologic evidence for past great earthquakes at the Cascadia subduction zone. Earthquake Spectra, 11: 1-18.

Atwater, B.F., Musumi-Rokkaku, S., Satake, K., Tsuji, Y., Ueda, K., Yamaguchi, D.K., 2005. The orphan tsunami of 1700-Japanese clues to a parent earthquake in North America. U.S. Geological Survey Professional Paper, 1707: 133 p. (published jointly by University of Washington Press, Seattle, Washington).

Berkeley, A., Perry, C.T., Smithers, S.G., Horton, B.P., Taylor, k.G., 2007. A review of the ecological and taphonomic controls on foraminiferal asselmblage development in intertidal environments. EarthScience Reviews, 83: 205-230.

Birks, H.J.B., 1995. Quantitative paleoenvironmental reconstructions. In: Maddy, D., Brew, J.S. (eds.) Statistical Modeling of Quaternary Science Data, Technical Guide no.5. Quaternary Research Association, Cambridge, 161-236.

Briggs, G.G., 1994, Coastal crossing of the zero-isobase, Cascadia margin, south-central Oregon coast [M.S.thesis]: Portland State University, Portland, Oregon, 251 p.

Bronk Ramsey, C., 2009. Bayesian analysis of radiocarbon dates. Radiocarbon, 51: 336-360.

Clague, J.J., Bobrowsky, P.T., 1994. Tsunami deposits beneath tidal marshes on Van couver Island, British Columbia. GSA Bulletin, 106: 1293-1303.

Clague, J.J. 1997. Evidence for large earthquakes at the Cascadia subduction zone. Reviews of Geophysics, 35: 439-460 
Darienzo, M.E., Perterson, C.D., 1990. Episodic tectonic subsidence of late Holocene salt marshes, northern Oregon central Cascadia margin. Tectonics, 9: 1-22.

Darienzo, M.E., 1991, Late Holocene paleoseismicity along the northern Oregon coast [Ph.D. thesis]: Portland State University, Portland, Oregon, 176 p.

Darienzo, M.E., Peterson, C.D., Clough, C., 1994. Stratigraphic evidence for great subduction-zone earthquakes at four estuaries in Northern Oregon, U.S.A. Journal of Coastal Research, 10: 850-876.

Darienzo, M.E., Peterson, C.D., 1995. Magnitude and frequency of subduction-zone earthquakes along the northern Oregon coast in the past 3000 years. Oregon Geology, 57: 3-12.

Dawson, A.G., Shi, S., Dawson, S., Takahashi, T., Shuto, N., 1996. Coastal sedimentation associated with the June 2nd and 3rd, 1994 tsunami in Rajegwesi, Java. Quat. Sci. Rev. 15, 901-912.

de Rijk, S., 1995. Salinity control on the distribution of salt-marsh foraminifera (Great-Marshes, Massachusetts). Journal of Foraminiferal Research, 25: 156-166.

Edwards, R.J., Horton, B.P., 2000. Reconstructing relative sea-level change using UK salt-marsh foraminifera. Marine Geology, 169: 41-56.

Eilers, H.P., 1975. Plants, plant communities, net production and tide levels - The ecological biogeography of the Nehalem tidal marshes, Tillamook county, Oregon: PhD dissertation, Oregon State University, Corvallis, 368p.

Flück, P., Hyndman, R.D., and Wang, K. 1997. Three-dimensional dislocation model for great earthquakes of the Cascadia subduction zone. Journal of Geophysical Research, 102: 20539 - 20550.

Gehrels, W.R., Roe, H.M., Charman, D.J., 2001. Foraminifera, testate amoebae and diatoms as sea-level indicators in UK saltmarshes: a quantitative multiproxy approach. Journal of Quaternary Science, 16: 201-220.

Gehrels, W.R., Hayward, B.W., Newnham, R.M., Southall, K.E., 2008. A $20^{\text {th }}$ century acceleration of sea-level rise in New Zealand. Geophysical Research Letters, 35: L02717, doi:10.1029/2007GL032632. 
Goldfinger, C., Grijalva, K., Burgmann, R., Morey, A.E., Johnson, J.E., Nelson, C.H., Guitierrez-Pastor, J., Ericsson, A., Karabanov, E., Chaytor, J., Patton, J., Gracia, E., 2008. Late Holocene rupture of the northern San Andreas fault and possible stress linkage to the Cascadia subduction zone. Bulletin of Seismological Society of America, 98: 861-889.

Grant, W.C. 1994. Paleoseismic evidence for late Holocene episodic subsidence on the Northern Oregon coast. [Ph.D. thesis]: University of Washington, Seattle: 176 pp.

Guilbault, J.-P., Clague, J.J., Lapointe, M., 1995. Amount of subsidence during a late Holocene earthquake-evidence from fossil tidal marsh foraminifera at Vancouver Island, west coast of Canada. Palaeogeography, Palaeoclimatology, Palaeoecology, 118: 49-71.

Guilbault, J.-P., Clague, J.J., Lapointe, M., 1996. Foraminiferal evidence for the amount of coseismic subsidence during a late Holocene earthquake on Vancouver Island, west coast of Canada. Quaternary Science Reviews, 15: 913-937.

Hamilton, S.L., Shennan, I., 2005a. Late Holocene land and sea-level changes and the earthquake deformation cycle around the upper Cook Inlet, Alaska. Quaternary Science Reviews, 24: 1479-1498.

Hamilton, S.L., Shennan, I., 2005b. Late Holocene great earthquakes and relative sea-level change at Kenai, southern Alaska. Journal of Quaternary Science, 20: 95-111.

Hawkes, A.D., Scott, D.B., Lipps, J.H., Combellick, R., 2005. Evidence for possible precursor events of megathrust earthquakes on the west coast of North America. Geological Society of America Bulletin, 117: 996-1008.

Hawkes, A.D., Bird, M., Cowie, S., Grundy-Warr, C., Horton, B.P., Tan Shau Hwai, A., Law, L., Macgregor, C., Nott, J., Eong Ong, J., Rigg, J., Robinson, R., Tan-Mullins, M., Tiong Sa, T., Zulfigar, Y., 2007. The Sediments Deposited by the 2004 Indian Ocean Tsunami Along the Malay-Thai Peninsula. Marine Geology Special IGCP 495 Issue, 242: 169-190.

Hawkes, A.D., Horton, B.P., Nelson, A.R., Hill, D.F., 2010. The application of intertidal foraminifera to reconstruct coastal subsidence during the giant Cascadia earthquake of AD 1700 in Oregon, USA. Quaternary International. 221, 116-140. 
Heaton, T.H., and Kanamori, H., 1984, Seismic potential associated with subduction in the northwestern United States, Bulletin of the Seismological Society of America, 74: 933-941.

Hemphill-Haley, E., 1995. Diatom evidence for earthquake-induced subsidence and tsunami 300 yr ago in southern coastal Washington. GSA Bulletin, 107: 367-378.

Hemphill-Haley, E., 1996. Diatoms as an aid in identifying late-Holocene tsunami deposits. The Holocene, 6: 439-448.

Horton, B.P., 1999. The contemporary distribution of intertidal foraminifera of Cowpen Marsh, Tees Estuary, UK: implications for studies of Holocene sea-level change. Palaeogeography, Palaeoclimatology, Palaeoecology, 149: 127-149.

Horton, B. P., Edwards, R. J., 2005. The application of local and regional transfer functions to reconstruct former sea levels, North Norfolk, England. The Holocene, 15 (2): 216-228.

Horton, B.P., Edwards, B.P., 2006. Quantifying Holocene sea-level change using intertidal foraminifera: lessons from the British Isles. Cushman Foundation for Foraminiferal Research, Special Publication, 40: 97 p.

Horton, B. P. and Murray, J. W., 2007. The roles of elevation and salinity as primary controls on living foraminiferal distributions: Cowpen Marsh, Tees Estuary, UK. Marine Micropaleontology, 63: 169-186.

Horton, B. P., Zong, Y., Hillier, C. and Engelhart, S., 2007. Diatoms from Indonesian mangroves and their suitability as sea-level indicators for tropical environments. Marine Micropaleontology, 63: 155-168.

Horton, B. P., Rossi, V. Hawkes, A. D., 2009. The Sedimentary Record of the 2005 Hurricane Season along the Gulf Coast, Quaternary International, 195: 15-30.

Hughes, J.F., Mathewes, R.W., Clague, J.J., 2002. Use of pollen and vascular plants to estimate coseismic subsidence at a tidal marsh near Tofino, British Columbia. Palaeogeography, Palaeoclimatology, Palaeoecology, 185: 145-161.

Hyndman, R.D., and Wang, K. 1993. Thermal constraints on the zone of major thrust earthquake failure: The Cascadia subduction zone. Journal of Geophysical Research, 98: 2039-2060. 
Hyndman, R.D., and Wang, K., 1995. The rupture zone of Cascadia great earthquakes from current deformation and the thermal regime: Journal of Geophysical Research, 100: 22,133-22,154.

Hyndman, R.D., Leonard, L.J., Currie, C.A., 2005. Test of models for the Cascadia great earthquake rupture area using coastal subsidence estimates for the 1700 earthquake. Final Report, US Geological Survey NEHRP External Grant Award 04HQGR0088, 11pp.

Jennings, A.E., Nelson, A. R., 1992. Foraminiferal assemblage zones in Oregon tidal marshes—relation to marsh floral zones and sea level. Journal of Foraminiferal Research 22: 13-29.

Kelsey, H.W., Witter, R.C., Hemphill-Haley, E., 2002. Plate-boundary earthquakes and tsunamis of the past 5500 yr, Sixes River estuary, southern Oregon. GSA Bulletin, 114: 298-314.

Kemp, A.C., Vane, C.H., Horton, B.P., and Culver, S.J., in press. Stable carbon isotopes as potential sealevel indicators in salt marshes, North Carolina, USA. Holocene.

Lamb, A.L., Vane, C.H., Wilson, G.P., Rees, J.G., Moss-Hayes, V.L., 2007. Assessing $\delta^{13} \mathrm{C}$ and C/N ratios from organic material in archived cores as Holocene sea level palaeoenvironmental indicators in the Humber Estuary, UK. Marine Geology, 244: 109-128.

Langezaal, A.M., Ernst, S.R., Haesse, R.R., van Bergen, P.F., van der Zwann, G.J., 2003. Disturbance of intertidal sediments: the response of bacteria and foraminifera. Estuarine, Coastal and Shelf Science, 58: 249-264.

Leonard, L.J., Hyndman, R.D., Mazzotti, S., 2004. Coseismic subsidence in the 1700 great Cascadia earthquake: Coastal estimates versus elastic dislocation models. GSA Bulletin, 116: 655-670.

Leonard, L.J., Currie, C.A., Mazzotti, S., and Hyndman, R.D. 2010 (in press). Rupture area and displacement of past Cascadia great earthquakes from coastal coseismic subsidence. Geological Society of America Bulletin.

Lloyd, J.M., Evans, J.R., 2002. Contemporary and fossil foraminifera from isolation basins in northwest Scotland. Journal of Quaternary Science, 17: 431-443.

Mamo, B., Strotz, L., Dominey-Howes, D., 2009. Tsunami sediments and their foraminiferal assemblages. Earth Science Reviews, v. 4, 263-278. 
Minor, R., Grant, W.C., 1996. Earthquake-induced subsidence and burial of late Holocene archaeology sites, Northern Oregon coast. American Antiquity, 61: 772-781.

Murray, J.M., Alve, E., 1999. Natural dissolution of modern shallow water benthic foraminifera: Thaphonomic effects on the palaeoecology record. Palaeogeography, Palaeoclimatology, Palaeoecology, Special Issue, 4: 195-209.

Nelson, A.R., 1992, Holocene tidal-marsh stratigraphy in south-central Oregon-Evidence for localized sudden submergence in the Cascadia subduction zone, in Fletcher, C.H., III, et al., eds., Quaternary coasts of the United States: Marine and lacustrine systems: SEPM (Society for Sedimentary Geology) Special Publication, 48: 287-301.

Nelson, A.R., Atwater, B.F., Bobrowsky, P.T., Bradley, L-A., Clague, J.J., Carver, G.A., Darienzo, M.E., Grant, W.C., Krueger, H.W., Sparks, R., Stafford, Jr., T.W., Stuiver, M., 1995. Radiocarbon evidence for extensive plate-boundary rupture about 300 years ago at the Cascadia subduction zone. Nature, 378: 371374.

Nelson, A.R., Jennings, A.E., Kashima, K., 1996a. An earthquake history derived from stratigraphic and microfossil evidence of relative sea-level change at Coos Bay, southern Oregon coast. GSA Bulletin, 108: 141-154.

Nelson, A.R., Shennan, I., and Long, A.J., 1996b, Identifying coseismic subsidence in tidal-wetland stratigraphic sequences at the Cascadia subduction zone of western North America: Journal of Geophysical Research, 101: 6115-6135.

Nelson, A.R., Kashima, K., 1993. Diatom zonation in southern Oregon tidal marshes relative to vascular plants, foraminifera, and sea level. Journal of Coastal Research, 9: 673-697.

Nelson, A.R., Peronius, S.F., 1996. Great earthquake potential in Oregon and Washington - an overview of recent coastal geologic studies and their bearing on segmentation of Holocene ruptures, central Cascadia Subduction zone: In Assessing earthquake hazards and reducing risk in the Pacific Northwest, Rogers, A.M., Walsh, T.J., Kockelman, W.J. and Priest, G.R. (eds), USGS Professional Paper, 1560: 91114. 
Nelson, A.R., Asquith, A.C., Grant, W.C., 2004. Great earthquakes and tsunamis of the past 2000 years at the Salmon River estuary, central Oregon coast, USA. Bulletin of Seismological Society of America, 94: 1276-1292.

Nelson, A.R., Ota, Y., Umitsu, M., Kashima, K., Matshushima, Y., 1998. Seismic or hydrodynamic control of rapid late-Holocene sea-level rise in southern coastal Oregon, USA? The Holocene, 8: 287299.

Nelson, A.R., Kelsey, H.M., Hemphill-Haley, E., Witter, R.C., 2006. Great earthquakes of variable magnitude at the Cascadia subduction zone. Quaternary Research, 65: 354-365.

Nelson, A.R., Sawai, Y., Jennings, A.E., Bradley, L-A., Gerson, L., Sherrod, B.L., Sabean, J., Horton, B.P., 2008. Great-earthquake palogeoesy and tsunamis of the past 2000 years at Alsea Bay, central Oregon coast, USA. Quaternary Science Reviews, 27: 747-768.

Okada, Y., 1985. Surface deformation due to shear and tensile faults in a half-space. Bulletin of the Seismological Society of America, 75: 1135-1154.

Ota, Y., Nelson, A.R., Umitso, M., Kashima, K., Matsushima, Y., 1995. Journal of Geography, 104: 94106.

Peterson, C. D., and Darienzo, M., 1988, Episodic tectonic subsidence of late Holocene salt marshes in Oregon: Clear evidence of abrupt strain release and gradual strain accumulation in the southern Cascadia margin during the last 3,500 years: U.S. Geological Survey Open-File Report 88-0541, 3 p.

Sabean, J.A.R., 2004. Applications of foraminifera to detecting land level change associated with great earthquakes along the west coast of North America. M.S. thesis, Dept Earth Sciences,Simon Fraser University, Burnaby, Bristish Columbia, 90 pp.

Satake, K., Wang, K., Atwater, B.F., 2003. Fault slip and seismic moment of the 1700 Cascadia earthquake inferred from Japanese tsunami descriptions. Journal of Geophysical Research, 108: 2535 p.

Scott, D.B., Medioli, F.S., Schafer, C.T., 2001, Monitoring in coastal environments using foraminifera and thecamoebian indicators: Cambridge University Press, London, 175 p. 
Scott, D.B., Medioli, F.S., 1980. Quantitative studies of marsh foraminifera distribution in Nova Scotia: Implications for sea-level studies. Cushman Foundation for Foraminiferal Research, Special Publication, 17: 1-58.

Shennan, I., Long, A.J., Rutherford, M.M., Green, F.M., Innes, J.B., Lloyd, J.M., Zong, Y., Walker, K.J., 1996. Tidal marsh stratigraphy, sea-level change and large earthquakes, I: a 5000 year record in Washington, USA. Quaternary Science Reviews, 15: 1023-1059.

Shennan, I., Long, A.J., Rutherford, M.M., Innes, J.B., Green, F.M., Kirby, J.R., Walker, K.J., 1998. Tidal marsh stratigraphy, sea-level change and large earthquakes, II: submergence events during the last 3500 years at Netarts Bay, Oregon, USA. Quaternary Science Reviews, 17: 365-393.

Troels-Smith, J., 1955. Characterization of unconsolidated sediments. Geological Survey of Denmark, Series IV 3, No. 10, 72pp.

Wang, K., Wells, R., Mazzotti, S., Hyndman, R.D., Sagiya, T., 2003. A revised dislocation model of interseismic deformation of the Cascadia subduction zone. Journal of Geophysical Research, 108: 20162029.

Wang, K., 2007. Elastic and viscoelastic models of crustal deformation in subduction earthquake cycles. In: Dixon, T., Moore, J.C. (Eds.), The Seismogenic Zone of Subduction Thrust Faults. Columbia University Press, New York, pp. 540-575.

Williams, H., Hutchinson, I., 2000. Stratigraphic and microfossil evidence for Late Holocene Tsunamis at Swantown Marsh, Whidbey Island, Washington. Quaternary Research, 54(2): 218-227.

Witter, R.C., Kelsey, H.M., Hemphill-Haley, E., 2003. Great Cascadia earthquakes and tsunamis of the past 6700 years, Coquille River estuary, southern coastal Oregon. GSA Bulletin, 115: 1289-1306.

Witter, R.C., Hemphill-Hailey, E., Hart, R., Gay, L., 2009. Tracking prehistoric Cascadia tsunami deposits at Nestucca Bay, Oregon. USGS Technical Report award number 08HQGR0076, 92pp.

Woodroffe, S.A., 2009. Recongnising subtidal foraminiferal assemblages: implications for quantitative sea-level reconstructions using a foraminifera-based transfer function. Journal of Quaternary Science, 24: 215-223. 
Woodward, J.A., White, J., Cummings, R., 1990. Paleoseismicity and the archaeological record: Areas of investigation on the Northern Oregon Coast. Oregon Geology, 52: 57-65. 


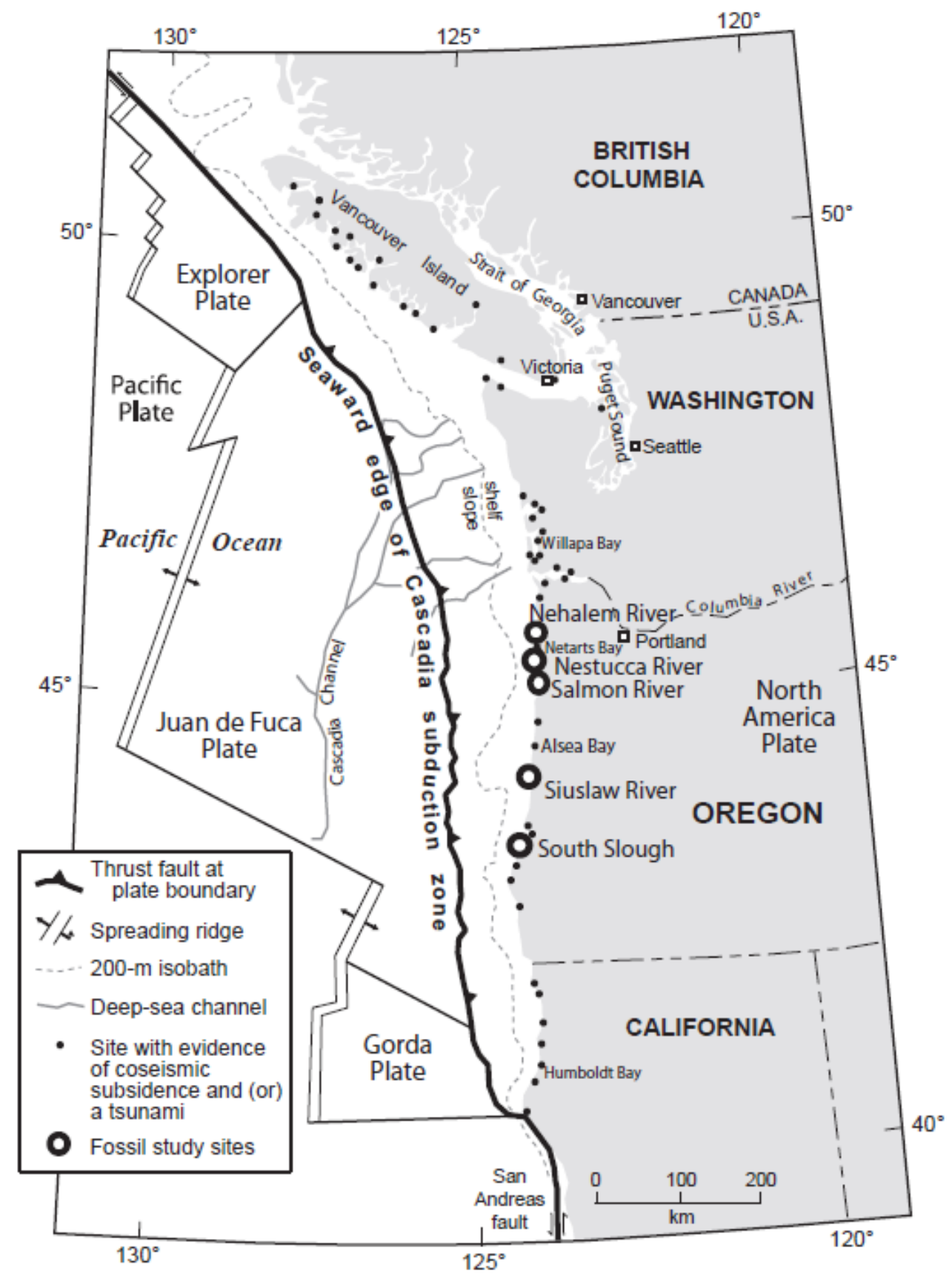


Figure 2

a)

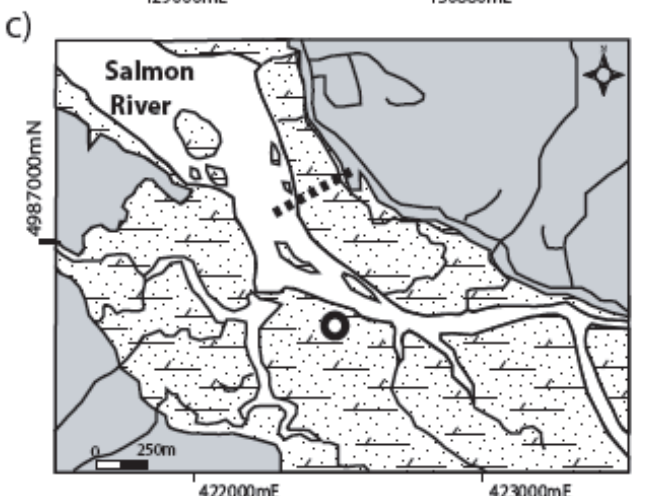

e)
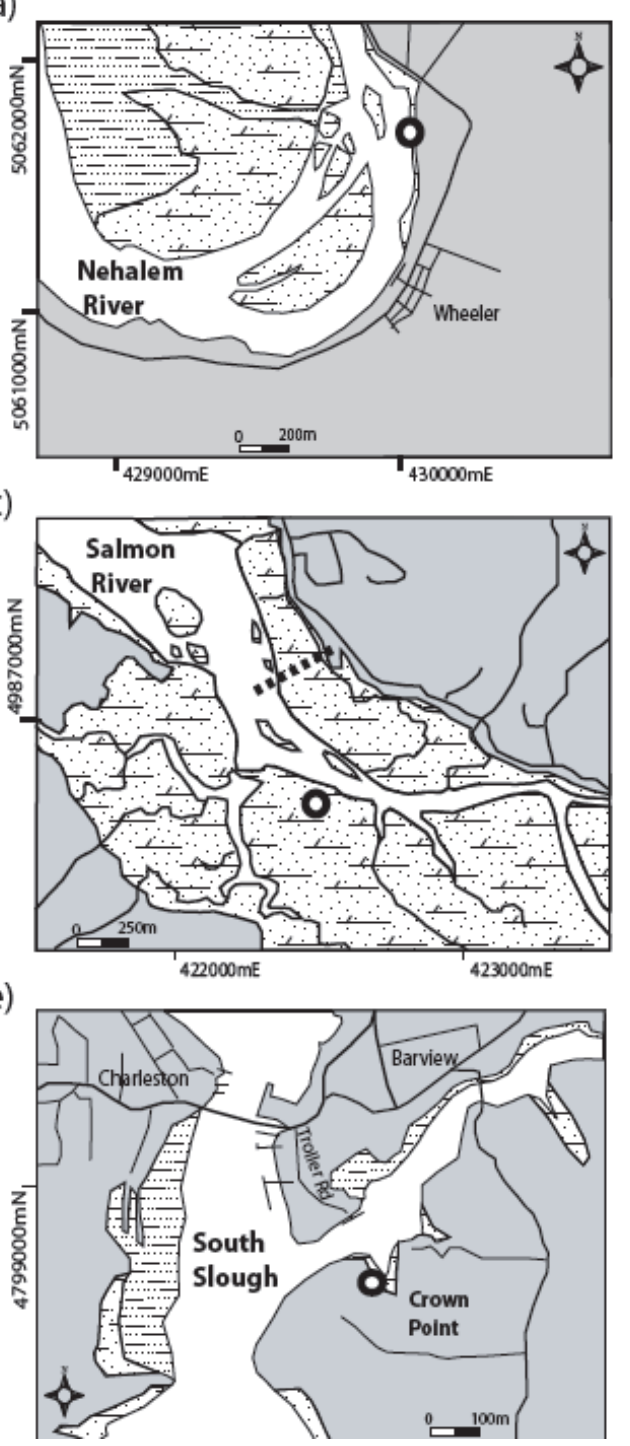

b)

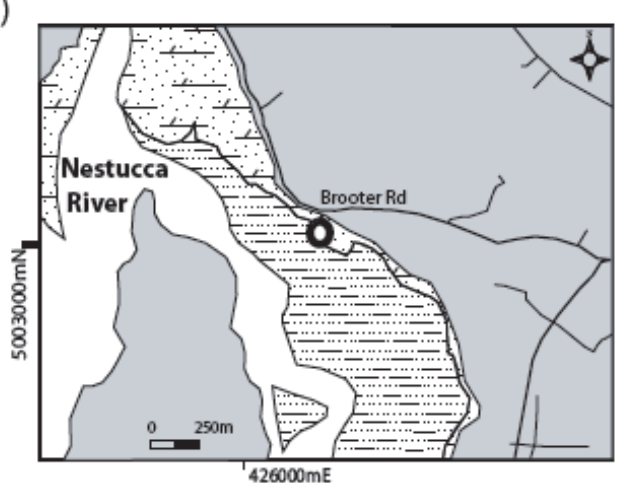

d)

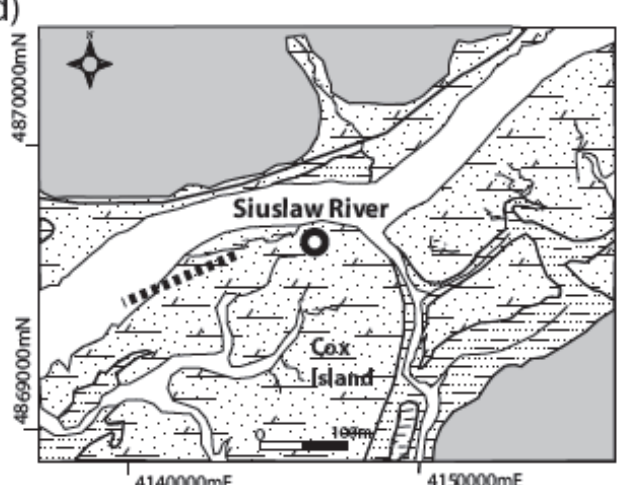

- core location

.... modern transect

marsh

tidal flat

water

upland

Fig 2 

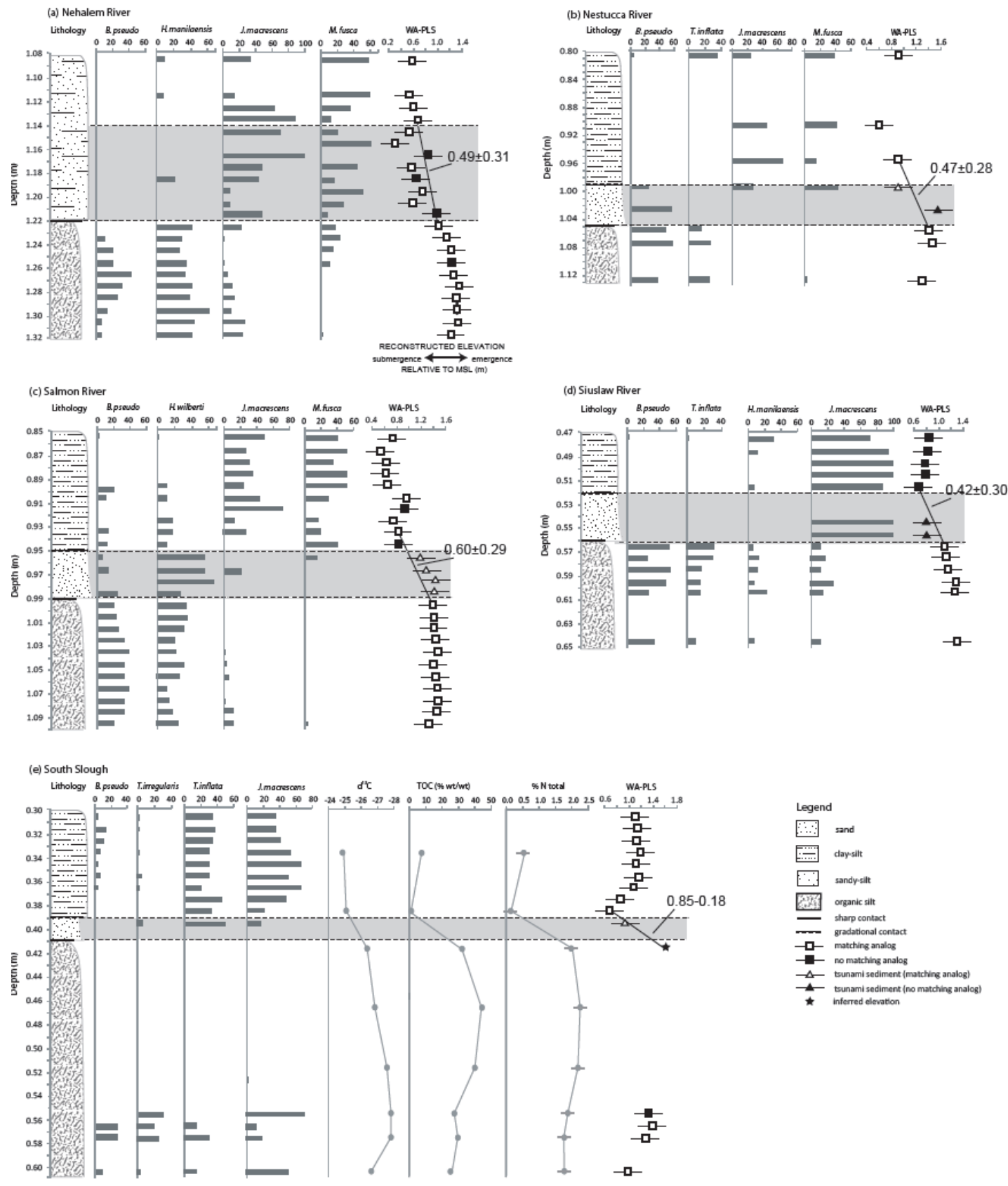

Fig 3 


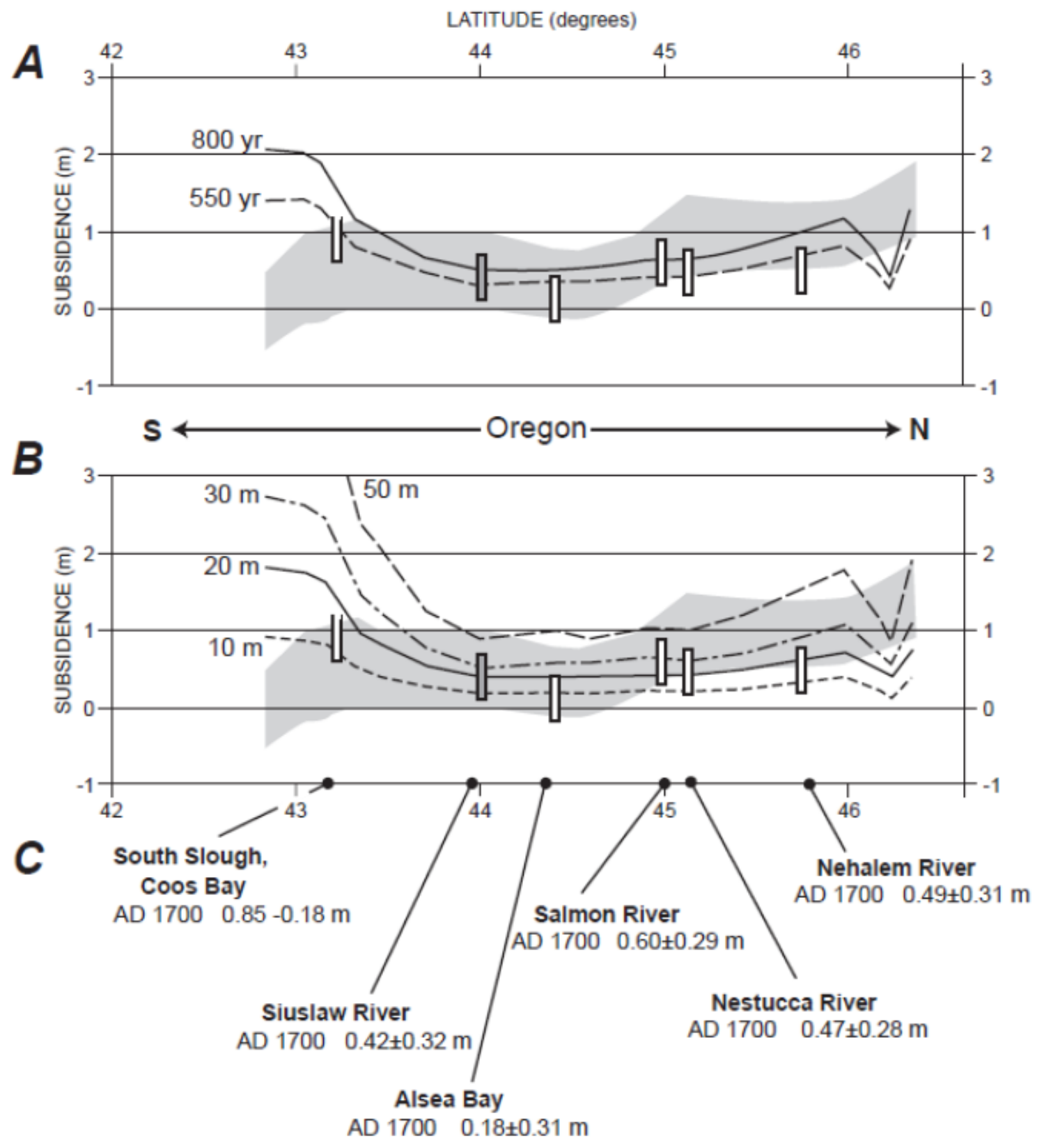

Fig 4 


\section{Table 1}

\begin{tabular}{|c|c|c|c|}
\hline Sites & $\begin{array}{l}\text { Leonard et al } \\
(2004,2010) \\
\text { subsidence } \\
\text { estimate } \\
\text { range }\end{array}$ & $\begin{array}{l}\text { Leonard et al } \\
(2004,2010) \\
\text { subsidence } \\
\text { mean and mean } \\
\text { uncertainty }\end{array}$ & $\begin{array}{l}\text { Hawkes et al } \\
\text { subsidence } \\
\text { estimates } \\
\text { from WA-PLS }\end{array}$ \\
\hline $\begin{array}{l}\text { Nehalem } \\
\text { River }\end{array}$ & 1.0 to $2.0 \mathrm{~m}^{*}$ & - & $0.49 \pm 0.31 \mathrm{~m}$ \\
\hline $\begin{array}{l}\text { Nestucca } \\
\text { River }\end{array}$ & $\begin{array}{l}0.7 \pm 0.5 \text { to } \\
1.25 \pm 0.5 \mathrm{~m}\end{array}$ & $0.95 \pm 0.35 \mathrm{~m}$ & $0.47 \pm 0.28 \mathrm{~m}$ \\
\hline $\begin{array}{l}\text { Salmon } \\
\text { River }\end{array}$ & 0.3 to $1.0 \mathrm{~m}^{* * *}$ & - & $0.60 \pm 0.29 \mathrm{~m}$ \\
\hline $\begin{array}{l}\text { Alsea } \\
\text { Bay }\end{array}$ & $\begin{array}{c}0 \pm 0.5 \text { to } \\
0.75 \pm 0.45 \mathrm{~m}\end{array}$ & $0.40 \pm 0.20 \mathrm{~m}$ & $0.18 \pm 0.31 \mathrm{~m}^{\dagger}$ \\
\hline $\begin{array}{l}\text { Siuslaw } \\
\text { River }\end{array}$ & $\begin{array}{c}0 \pm 0.5 \text { to } 1.1 \\
\pm 0.5 \mathrm{~m}\end{array}$ & $0.53 \pm 0.31 \mathrm{~m}$ & $0.42 \pm 0.30 \mathrm{~m}^{\ddagger}$ \\
\hline $\begin{array}{l}\text { South } \\
\text { Slough }\end{array}$ & $\begin{array}{c}0 \pm 0.5 \text { to } 1.1 \\
\pm 0.6 \mathrm{~m}\end{array}$ & $0.61 \pm 0.32 \mathrm{~m}$ & $0.85-0.18 \mathrm{~m}^{\dagger \dagger}$ \\
\hline
\end{tabular}

Subsidence estimate range and subsidence mean and mean uncertainty are derived from Leonard et al. (2004, 2010 and references therein with the exception of Hawkes et al., 2008 which the present paper reports an updated reconstruction). *Denoted estimates that have been interpolated from Leonard et al. 2004. ${ }^{\dagger}$ Estimate derived from fossil data of Nelson et al. (2008) in Hawkes et al (2010), reconstruction may be hampered by taxonomic dispcrepancies. ${ }^{\text {tE}}$ Estimate has no matching analogues in the post-seismic sediment and therefore calculated coseismic subsidence is to be used with caution. ${ }^{+1}$ Pre-seismic elevation is inferred from the modern transect of Hawkes et al. 2010 at South Slough because no microfossils were present in the sediment underlying the earthquake contact.

Table 1 
